\title{
Microsatellites and RAPD markers to study genetic relationships among cowpea breeding lines and local varieties in Senegal
}

\section{Diaga Diouf · Khidir W. Hilu}

Published online: 23 September 2006

(C) Springer Science+Business Media B.V. 2006

Due to technical problems Figure 1B was printed too dark in Genet Resour Crop Evol 52 page 1062.

The online version of the original article can be found at http://dx.doi.org/10.1007/s10722-004-6107-z

D. Diouf

Laboratoire de Biotechnologies Végétales, Faculté des Sciences et Techniques, Université Cheikh Anta Diop, B.P. 5005, Dakar, Sénégal

K. W. Hilu $(\bowtie)$

Department of Biology, Virginia Polytechnic Institute and State University, Blacksburg, VA 24061-0406,

USA

e-mail: hilukw@vt.edu 
Fig. 1 Amplification of RAPD markers using primer A14 (1A) and SSR using primer VM30 (1B) from 11 cowpea varieties. Lane $\mathrm{M}$ contains molecular weight marker of 100 Base-pair Ladder; lanes $\mathrm{E}$ and $\mathrm{C}$ is a control (without DNA). Lanes 1-15 represents the varieties studied: 58 74(1); Ndiaga Aw (2); Diongoma (3); CB5 (5); Baye Ngagne (6); Melakh (8); Bambey 21(9); 6635(10); 58-57(12);

Mougne (13); Mouride (15)

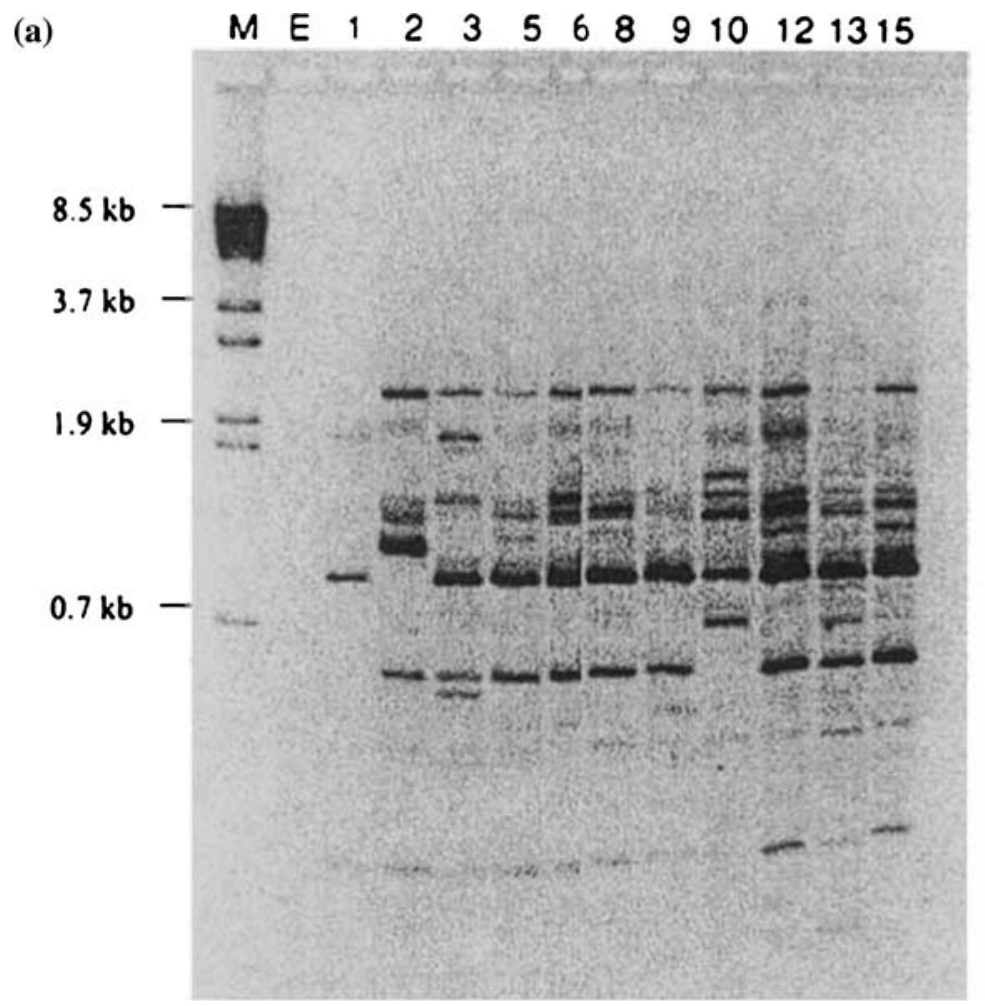

(b)

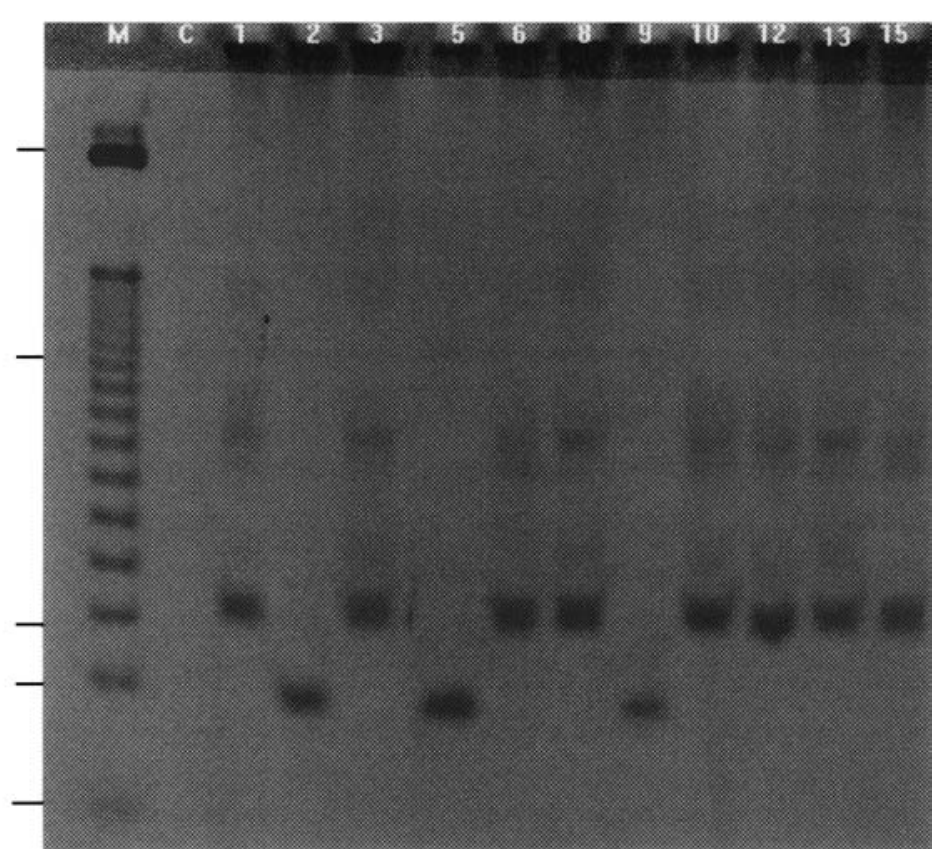

